\title{
Soil, pasture and animal product quality
}

\author{
Marcella Avondo, ${ }^{1}$ Pierlorenzo Secchiari, ${ }^{2}$ Luca Maria Battaglini, ${ }^{3}$ Adriana Bonanno, ${ }^{4}$ \\ Giuseppe Pulina ${ }^{5}$ \\ 'Dipartimento di Scienze delle Produzioni Agrarie e Alimentari, Università di Catania; \\ ${ }^{2}$ Dipartimento di Scienze Agrarie, Alimentari e Agro-ambientali, Università di Pisa; ${ }^{3}$ Dipartimento \\ di Scienze Agrarie, Forestali e Alimentari, Università di Torino; ${ }^{4}$ Dipartimento Scienze Agrarie e \\ Forestali, Università di Palermo; ${ }^{5}$ Dipartimento di Agraria, Università di Sassari, Italy
}

\begin{abstract}
The management of pasture, through the use of appropriate stocking rates and grazing systems, influences the feeding behaviour of the animals. The impact of animal behaviour on vegetation can be of great importance for the sustainability of pastures and mantaining their biodiversity. Indeed, a different response in terms of quality of animal products is mediated by the ability of animals to concentrate or transform grass components, according to the characteristics of the soil. The herbage ingested by animals provides them with compounds with aromatic characteristics, such as terpenes, and with functional properties beneficial for human health, such as carotenoids, vitamins, polyphenols and polyunsatured fatty acids. The combination of different ecological conditions on different soils through specific management practices determines the differentiation of several pasture vegetation types, a unique patrimony of great value in terms of biodiversity and capability to sustain local production, also important because of their own high added value. This review deals with pasture management aimed at conserving the soil and reducing gas emissions, and takes into consideration the quality of animal products as a result of such management.
\end{abstract}

Correspondence: Marcella Avondo, Dipartimento di Scienze delle Produzioni Agrarie e Alimentari, Università di Catania, Italy.

E-mail: mavondo@unict.it

Key words: grazing management, pasture biodiversity, product quality, soil conservation.

Conference presentation: AISSA Palermo, 2012.

Società rappresentata nell'ambito AISSA: Associazione per la Scienza e le Produzioni Animali - ASPA.

Received for publication: 25 May 2013.

Revision received: 3 July 2013.

Accepted for publication: 4 July 2013.

(C) Copyright M. Avondo et al., 2013

Licensee PAGEPress, Italy

Italian Journal of Agronomy 2013; 8:e19

doi:10.4081/ija.2013.e19

This article is distributed under the terms of the Creative Commons Attribution Noncommercial License (by-nc 3.0) which permits any noncommercial use, distribution, and reproduction in any medium, provided the original author(s) and source are credited.

\section{Introduction}

Livestock farming systems in many areas, particularly in hills and mountain environments, have for centuries contributed to the integration between territorial vocation and manufacturing processes while maintaining local production, defined according to the specific characteristics as terroir (Grappin and Coulon, 1996; Bugaud et al., 2001). A terroir (e.g. related to a cheese) is the result of the relationship between different factors: soil, climate, vegetation, animal breed, grazing techniques, processing technologies, etc. Soil conditions strongly influence floristic characteristics, production and quality of pastoral vegetation. These characteristics are, in turn, of fundamental importance to confer special properties to the products of these environments. Conservation of the diversity of pasture types, as well as the ecological and landscape diversity, is a pre-requisite for the conservation of agro-pastoral and livestock production activities and for the development of tourism and recreational activities as a means to promote the sustainable development and economy of alpine (Ramanzin et al., 2009; Battaglini et al., 2003a) and hills areas. However, in the last half-century, difficulties in maintaining these activities have emerged, due to low profitability and poor quality of life for the farmers. This has led to degradation and loss of soil due to land abandonment. The loss of the link between breeding, territory and product has clearly led to the impoverishment of the soil and the deterioration of vegetation biodiversity (Gusmeroli et al., 2010; Gusmeroli, 2012). Furthermore, if on the one hand animals are to be considered the only way to maintain the sward and contain erosion in these areas, on the other hand they are often considered a source of hydro-geological and environmental risk, due to their action of soil compaction, of depletion of plant biodiversity, and even for their greenhouse effect. Following the review by Enne et al. (2002), it can be said that agro-pastoral activities are one of the main causes of land degradation in Mediterranean areas. Even though, over the past two centuries, overgrazing has been a problem in southern Italy and the islands, the current heavy reduction in livestock has now greatly reduced the phenomenon (Sepe et al., 2011). However, the problem remains serious on the southern shore of the Mediterranean and in Sub-Saharan Africa. In these systems, only appropriate grassland management can restore the optimal animalplant-soil relationship.

\section{Overgrazing and soil degradation}

The negative effects of overgrazing on the soil are direct (trampling) and indirect (reduction of vegetation cover) (Enne et al., 1998). A high number of grazing animals per hectare may cause soil compaction, surface horizon disruption, reduction in infiltration, creation 
of terracing on step slopes, development of animal trails. The degree of this impact on a specific site depends on the interaction between vegetation, soil, weather and animal. The poaching of soil by hooves reduces soil porosity that, in turn, reduces water infiltration and percolation. This leads to an increase in water runoff and erosion on steep terrain, and favours hydromorphism or stagnation on plains. Soil compaction depends on animal behaviour (such as to run or to graze in groups) and on the shepherd's management (concentration areas due to shade or trees, area protected from predominant winds, drinking points and artificial feeding points, etc.). Compaction depends on the stocking rate and on the specific pressure of the hooves per $\mathrm{cm}^{2}$. Enne et al. (1998), measuring the hoof area and the body weight of various animals, estimated an average pressure per unit area of $0.47 \mathrm{~kg} \mathrm{~cm}^{-2}$ for sheep, $0.98 \mathrm{~kg} \mathrm{~cm}^{-2}$ for cattle, and $1.01 \mathrm{~kg} \mathrm{~cm}^{-2}$ for donkey. When soils are wet and clay-textured, or the vegetation cover is scarce, it is more likely that the destruction of the surface by penetration of hooves occurs. Livestock management, such as allowing grazing during the wet winter months or high stocking rate at any time, may accentuate damage to soil properties. The routes chosen by animals while grazing and being transferred from one pasture to another may result in terracing on sloping terrain or in trails on flatter ones. Trails become areas of bare soil with high stocking and low availability of forage; these areas can cover a high proportion of the grazing area, mainly at waiting areas near gates or drinking points. Overgrazing may remove part of the vegetation cover which, in its turn, brings about an increase in raindrop in path and surface soil crusting, and a decrease in organic soil matter, aggregate stability, and water infiltration rate (d'Angelo et al., 1999). The soil organic matter, an important component in its fertility, is essential for the maintenance of good structure that counteracts the erosive action of the water and wind. Animals remove organic matter by their products, respiration and fermentation gasses, and they represent the balance between the amount of dry matter consumed and the dry matter returned to the soil in the form of faeces and urine. The quantity of organic matter actually returned by animals and incorporated into the soil is not easy to estimate. Restitutions are efficient only during wet seasons, when faeces are easily incorporated into the soil because they are soft as a consequence of the animals' intake of fresh grass. In contrast, the faeces are drier in the summer seasons as a result of feeding on stubble and metabolic mechanisms that protect animals from wasting water. Dry faeces can remain on the soil surface for months and are likely to be completely oxidised (Pulina et al., 1995).

\section{Undergrazing and soil degradation}

The phenomenon of extensification and abandonment of several marginal areas with a reduction in the pressure from agricultural activities has allowed initiation of naturalisation processes. The first consequence of this is an alteration in the botanical composition of the grazing-lands resulting in invasion by non-pastoral herbaceous species, followed by shrubs giving a homogeneous land cover not suitable for grazing (Papanastasis, 1999). In these cases, there is a clear increase in the amount of unutilised grass, accumulation of dead biomass, spread of unpalatable species, and a reduction in low-growing herbs, even if, in some cases, a moderate stocking density is important to allow plants to flower and seed. It is also true that low stocking rates, particularly in rich soil conditions, can generate benefits to plant ecosystems such as reducing invasion from weeds and improving degraded land and promoting healthy soil (Heitschmidt and Stuth, 1991). Low stocking rates necessarily lead to an impoverishment of the surfaces with the effects of quality deterioration of pastoral vegetation. For example, facies that are relatively poor from a pastoral point of view (e.g. Nardus stricta, Festuca ovina) are significantly degraded if not regularly used during the pasture season. To deal with these effects, we need to maintain an adequate grazing management for environmental conservation through a pastoral plan, giving careful consideration to: i) the extension of the area that has to be maintained; ii) the distribution between herbaceous and invasive species cover; iii) the type of vegetation to be controlled; iv) the forage value of pastoral vegetation; v) the stocking rates; vi) the grazing techniques; and vii) the exploitation schedule. A pasture-type approach has to be applied where a large-scale grazing management plan is required to prevent the negative ecological effects on biodiversity and landscape of a reduced stocking rate and very extensive exploitation (Argenti and Lombardi, 2012).

\section{Grazing systems}

An appropriate grazing management of hill and mountain areas, based on a sustainable stocking rate and a controlled grazing technique, aims to achieve a high and prolonged herbage production, to ensure the animals can satisfy their nutritional needs, optimise their welfare, health status and productivity, and also to obtain safer and more beneficial animal products for consumers. For these systems, suitable species and breeds should be chosen, possibly autochthonous, for their beneficial effects upon animal health and product characteristics. In fact, they can adapt to particularly difficult climatic and soil conditions that will then influence the quality of the spontaneous pasture (Battaglini et al., 2006).

In a grazing system, stocking rate is one of the main factors influencing the soil-plant-animal interactions, and when properly modulated in relation to herbage allowance it has a positive impact on animal voluntary intake and productivity (Table 1). In general, as stocking rate increases, the individual animal performance decreases, whereas the animal production per hectare initially increases and then decreases passing to higher stocking rates. Therefore, the optimal stocking rate for a grazing system is the value corresponding to the maximum production per hectare (Inyang et al., 2010). In line with this trend, milking goats grazing a ryegrass and berseem clover mixture for $7 \mathrm{~h} / \mathrm{d}$ at different stocking rates $(72,48$ and 36 heads/ha) reached the maximum milk yield per hectare when grazed at medium intensity (48 heads/ha) (Bonanno et al., 2007a).

However, the ingestive and productive responses of grazing animals to herbage allowance also greatly depend on grazing technique, i.e. continuous or rotational. The grazing system based on field rotation, where grazing periods are alternated with periods of vegetation rest to ensure plant re-growth, seems to have a greater potential in terms of herbage production and utilisation rate by grazing animals than continuous grazing. Moreover, due to the shorter permanence in the field, this system prevents the risk of spreading parasitic infestation by faecal contamination of crops (Barger et al., 1994). However, the productive advantages of the rotational grazing remain controversial, since several researches have shown how the higher productivity of rotational pasture is not always converted into the expected improvement in animal production (Cavallero and Ciotti, 1991; Boval and Dixon, 2012). Indeed, researches carried out in Sicily on dairy goats (Bonanno et al., 2008) and ewes (Di Grigoli et al., 2012) grazing forage crops according to continuous or rotational systems, showed that the increased availability of forage biomass from pasture rotation did not correspond to an increase in herbage intake or animal milk yields (Table 1), justified mainly by the reduced nutritive value and palatability of forage due to the excessive ageing of leaf tissue of grazed plants. 


\section{Modelling a sustainable stocking rate}

The impact of grazing animals on soil degradation has to be seen primarily within a territorial context. This means there is a need for a tool designed to understand, plan and manage the complex animal-vegetation-soil interaction in relation to land degradation processes. Pulina et al. (2002) have developed a computer-aided model to calculate the environmental impact of a given livestock stocking rate from a local to a regional scale [Environmental Impact of Animal Stocking: Carico Animale di Impatto Ambientale (CAIA)] which arises from a mathematical combination of two sub-models: the actual CAIA model (Pulina et al., 1999) and the model for evaluating the suitability of grazing land (Madrau et al., 1999).

Iocola et al. (2009) have developed the CAIA model by using the ratio of the two sub-models (actual CAIA:sustainable CAIA) and expressing the ratio as a 5-point grazing intensity index (GII) from 0 (land with no grazing impact, i.e. grazing activities in these land units allow economic benefits without environmental risks) to 1.0 (land hardly ever overgrazed in already highly degraded areas, i.e. these condition would stop any grazing activities). They called the model CAIA.2 and evaluated the map accuracy by comparing the results of the automatic classification with field surveys. They then implemented the CAIA.2 model in a geographic information system environment by a script (d'Angelo et al., 2000) which supplies Visual Basic Language (Microsoft Corp., Redmond, WA, USA) and ArcObject ${ }^{\circledR}$ (Esri, Redlands, CA, USA) commands. The model was applied to the whole Sardinia region, comparing the risk of over-grazing between 1995 and 2005. The elaboration of any input data was defined for every single farm pasture area of Sardinia.

The output of the model (Figure 1) shows that, in ten years, the overgrazing risks have worsened because the areas with GII of 0.75 or over have increased. The farms that suffered from severe overgrazing are mainly located in the central areas of the island where soil fertility is generally low and the stocking rate is high. The Authors concluded that the CAIA.2 model application shows a good reliability for interpreting the over-grazing impact and evaluating the land suitability for a grazing ecosystem. So, it can be considered a valid tool to support decision making in a sustainable rural development.

\section{Soil carbon capture and pastoral farming}

Livestock activities on pastoral surfaces can be considered as lowimpact also as regards $\mathrm{CO}_{2}$ emissions; these systems represent an interesting pattern of sustainable integration between surface management and overall production procedures. However, during the last decades, alpine valley-floors have seen a general reduction in the use of pastoral surfaces and an increase in the number of farms with highly productive dairy cattle, using high amounts of concentrates with direct and indirect effects also upon greenhouse gas emissions (GHG). Therefore, while traditional pastoral activities would be mostly neutral in terms of $\mathrm{CO}_{2}$ emissions, livestock systems less consistent with the pastoral territory would be characterised by particularly high emissions. It is well known that carbon (C) capture in the soil represents the solution for mitigating GHG production in agriculture. $\mathrm{C}$ capture on pastoral surfaces can be directly determined by means of measuring changes in organic $\mathrm{C}$ in the soil or indirectly by measuring variations in $\mathrm{C}$ fluxes. This could be taken into careful consideration in order to mitigate emissions in animal production. Changing grazing surface use (e.g. soil processing, conversion into crops, use of agricultural territory for other aims) should also be avoided and a suitable pastoral management plan adopted to conserve and recover land and improve its organic substance (Garnett, 2010). Such activities, along with a lower use of $\mathrm{N}$ from synthesis fertilisers, fossil energy and proteic feeds (e.g. soybean) coming from sites often very far away from these areas, might lead to a major reduction in emissions per surface unit and per animal unit.

In order to reduce $\mathrm{C}$ losses and increase $\mathrm{C}$ held, deep soil processing and conversion of grazing lands into arable land are to be avoided. On the contrary, it would be good to increase the use of low-production natural grazing lands, to adopt less intensive grazing practices through low animal charges, lengthen the grazing season, and re-convert crop

Table 1. Effects of stocking rate at pasture and grazing techniques on dry matter intake and milk yield of small ruminants.

\begin{tabular}{|c|c|c|c|c|c|c|c|}
\hline & $\begin{array}{l}\text { Experimental } \\
\text { groups }\end{array}$ & $\begin{array}{l}\text { Animal } \\
\text { species }\end{array}$ & Pasture & $\begin{array}{c}\text { Forage biomass } \\
\text { (t/ha DM) }\end{array}$ & $\begin{array}{l}\text { DM intake } \\
(\mathrm{g} / \mathrm{d})\end{array}$ & $\begin{array}{l}\text { Milk yield } \\
(\mathrm{g} / \mathrm{d})\end{array}$ & Reference \\
\hline Stocking rate, no. heads/ha & $\begin{array}{l}36 \\
48 \\
72\end{array}$ & Goats & $\begin{array}{l}\text { Italian ryegrass } \\
\text { and berseem } \\
\text { clover mixture }\end{array}$ & $\begin{array}{l}4.3^{\mathrm{a}} \\
4.2^{\mathrm{a}} \\
3.4^{\mathrm{b}}\end{array}$ & $\begin{array}{l}1246^{\mathrm{a}} \\
1155^{\mathrm{b}} \\
1075^{\mathrm{c}}\end{array}$ & $\begin{array}{l}1332^{\mathrm{a}} \\
1328^{\mathrm{a}} \\
1004^{\mathrm{b}}\end{array}$ & Bonanno et al., 2007a \\
\hline Stocking rate, no. heads/ha & $\begin{array}{l}30 \\
50 \\
70\end{array}$ & Goats & 1-year sulla & $\begin{array}{l}4.7^{\mathrm{a}} \\
3.1^{\mathrm{b}} \\
2.4^{\mathrm{c}}\end{array}$ & $\begin{array}{l}1353^{\mathrm{a}} \\
1185^{\mathrm{b}} \\
1069^{\mathrm{b}}\end{array}$ & $\begin{array}{l}1763^{\mathrm{a}} \\
1516^{\mathrm{b}} \\
1361^{\mathrm{c}}\end{array}$ & Bonanno et al., 2007b \\
\hline Stocking rate, no. heads/ha & $\begin{array}{l}23 \\
38\end{array}$ & Ewes & $\begin{array}{c}\text { Italian ryegrass and } \\
\text { berseem clover mixture }\end{array}$ & $\begin{array}{l}2.1^{\mathrm{a}} \\
1.8^{\mathrm{b}}\end{array}$ & $\begin{array}{l}- \\
-\end{array}$ & $\begin{array}{l}1300^{\mathrm{a}} \\
1130^{\mathrm{b}}\end{array}$ & Di Grigoli et al., 2009 \\
\hline $\begin{array}{l}\text { Grazing techniques, } \\
\text { no. heads/ha }\end{array}$ & $\begin{array}{l}\text { Continuous, } 32 \\
\text { Rotational, } 36\end{array}$ & Goats & $\begin{array}{c}\text { Italian ryegrass } \\
\text { and berseem clover } \\
\text { mixture }\end{array}$ & $\begin{array}{l}4.3 \\
3.6 \\
\end{array}$ & $\begin{array}{l}1240 \\
1095 \\
\end{array}$ & $\begin{array}{l}1332 \\
1027 \\
\end{array}$ & Bonanno et al., 2008 \\
\hline $\begin{array}{l}\text { Grazing techniques, } \\
\text { no. heads/ha }\end{array}$ & $\begin{array}{c}\text { Continuous, } 25 \\
\text { Rotational, } 25 \\
\text { Continuous, } 25 \\
\text { Rotational, } 25\end{array}$ & Ewes & $\begin{array}{l}\text { Oats and berseem } \\
\text { clover mixture } \\
\text { 2-year sulla }\end{array}$ & $\begin{array}{l}1.9 \\
2.6 \\
2.5 \\
4.2 \\
\end{array}$ & $\begin{array}{l}200^{* a} \\
180^{* b} \\
161^{* \mathrm{c}} \\
141^{* \mathrm{~d}}\end{array}$ & $\begin{array}{c}1003^{\mathrm{a}} \\
934^{\mathrm{b}} \\
1137^{\mathrm{a}} \\
969^{\mathrm{b}}\end{array}$ & Di Grigoli et al., 2012 \\
\hline
\end{tabular}

DM, dry matter. a,b,c,d $\mathrm{P} \leq 0.05 ;$ *Time (min/d) ewes spent eating at pasture. 
lands and artificial swards to permanent grasslands or pastures (Soussana et al., 2010).

Research studies, such as the European Carbomont project, have tried to determine $\mathrm{C}$ balance through the analysis of traditional pasture systems with the aim of evaluating the reduction in GHG emissions in function of short-term climatic variations and of different management practices (Rogiers et al., 2008).

\section{Grazing behaviour and pasture biodiversity}

The animal-plant interaction determines important effects on vegetation, pasture biodiversity and land cover. Pasture grazing involves a selective behaviour that differs greatly between animal species. There is a wider choice activity the greater the animal's ability to acquire the preferred diet through grazing, in relation to the conformation of their mouth (Rosenthal et al., 2012). Cattle take up the herbage with their pre-hensile tongue and cut it with the incisors through a movement of the head; for this reason, they are not able to precisely choose individual species or portions of plants. On the contrary, sheep and goats, with their small mouth and very mobile lips, can easily grab leaves, buds or preferred botanical species, even in very complex mixtures. In fact, cattle are unable to select within patches and, therefore, tend to select between patches, moving in areas rich in more palatable essences and leaving undisturbed areas that are of less interest to them. Indeed, cattle tend to avoid areas around deposited dung pats. This, together with grazing and trampling, can be considered to be one of the most important factors explaining vegetation structure in pastures (Kohler et al., 2004, Gillet et al., 2010)

Selection determines changes in the vegetation (Rook et al., 2004) that, depending on the degree of choice involved, can be positive or negative. At low stocking rates, when there is strong selection, tall unpalatable plants can develop, resulting in a mosaic landscape structure. Paradoxally, in this condition cattle, preferring some patches to others, can cause local overgrazing (Metera et al., 2010). At very high stocking rates, sheep and goats with their small mouths, and horses with their mobile lips and upper and lower incisors, are able to graze closer than cattle to the vegetation that could potentially damage the soil.

In contrast, moderate selection promotes: i) opening of the biomass canopy to allow more light penetration of the sward, creates greater opportunities for growth for some minor essences, and increases species richness (Soder, 2007); ii) movement of animals in search of more desirable species resulting in the spread of seeds through the faeces or fleece; iii) structural heterogeneity that determines the formation of microhabitat with different floristic composition.

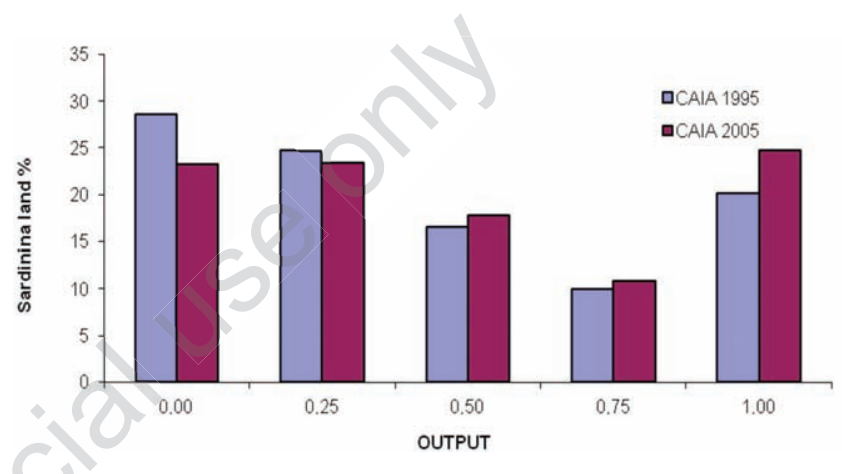

Figure 1. CAIA.2 output for Sardinia. Comparison between 1995 and 2005. Grazing intensity index (0.00 no overgrazing; 1.00 severe overgrazing). The area is expressed as percentage of 1 million on hectares grazed on the island. CAIA, Carico Animale di Impatto Ambientale.

Table 2. Effects of pasture-based diet on the content of aromatic and functional compounds in Caciocavallo Palermitano cheese.

\begin{tabular}{|c|c|c|c|}
\hline Diet & Pasture & Hay and concentrate & Reference \\
\hline Terpenes $(\mu \mathrm{g} / \mathrm{kg})$ & $35.4^{\mathrm{a}}$ & $11.5^{\mathrm{b}}$ & Bonanno et al., 2004 \\
\hline Trans-retinol ( $\mu \mathrm{g} / 100 \mathrm{~g})$ & 235 & 206 & \\
\hline 13-cis retinol $(\mu \mathrm{g} / 100 \mathrm{~g})$ & $59.9^{\mathrm{a}}$ & $32.7^{\mathrm{b}}$ & \\
\hline$\alpha$-tocopherol ( $\mu \mathrm{g} / 100 \mathrm{~g})$ & $1301^{\mathrm{a}}$ & $823^{b}$ & \\
\hline \multicolumn{4}{|l|}{ FA ( $\%$ FAME) } \\
\hline trans-11 C18:1 (VA) & $2.57^{\mathrm{a}}$ & $1.32^{\mathrm{b}}$ & Bonanno et al., 2013 \\
\hline cis-9 C18:1 (oleic) & 18.8 & 20.8 & \\
\hline cis-9, cis-1 C18:2n-6 (linoleic) & $1.62^{\mathrm{b}}$ & $2.45^{\mathrm{a}}$ & \\
\hline cis-9, trans-11 C18:2 (rumenic, CLA) & $1.09^{\mathrm{a}}$ & $0.66^{\mathrm{b}}$ & \\
\hline C18:3n-3 ( $\alpha$-linolenic, ALA) & $1.19^{a}$ & $0.62^{b}$ & \\
\hline Saturated FA & 66.6 & 66.0 & \\
\hline Monousaturated FA & $26.8^{b}$ & $28.4^{\mathrm{a}}$ & \\
\hline Polyunsaturated FA & $4.98^{\mathrm{a}}$ & $4.40^{b}$ & \\
\hline Saturated/unsaturated FA & 2.12 & 2.02 & \\
\hline$\sum$ n-6 (omega 6) & $1.72^{\mathrm{b}}$ & $2.65^{\mathrm{a}}$ & \\
\hline $\bar{\sum}$ n-3 (omega 3) & $1.47^{\mathrm{a}}$ & $0.85^{\mathrm{b}}$ & \\
\hline$n-6 / n-3$ & $1.28^{b}$ & $3.43^{\mathrm{a}}$ & \\
\hline OBCFA & $6.12^{\mathrm{a}}$ & $4.68^{b}$ & \\
\hline
\end{tabular}

a,bP $\leq 0.05$. FA, fatty acids; FAME, fatty acid methyl esters; VA, vaccenic; CLA, conjugated linoleic acid; ALA, $\alpha$-linolenic acid; OBCFA, odd and branched chain fatty acids. 
In summary, therefore, when contained within certain limits, for example, thanks to a proper management of the stocking rate, selection increases the biodiversity of the pasture. But what does this mean for the animals? The increased availability and the more continuous distribution of biomass during the different seasons, thanks to the complementarity of nutritional and climatic requirements of different plant species, leads to higher ingestion of herbage and, consequently, higher animal performance. Species richness increases intake because the animal perceives the advantages of taking in new nutrients from different species and diluting those ingested with the previous meal. In fact, as demonstrated by Provenza et al. (2003), the animals tend to mix plant species to enhance the nutrient content of the selected diet and to limit toxic concentrations of plants, searching for curative essences. A lower nitrogen excretion of animals grazing in pastures rich in essences has also been observed in comparison to rye-grass and white clover swards (Totty et al., 2013). As suggested by the Authors, the two factors that could have reduced nitrogen $(\mathrm{N})$ excretion are the higher ratio between soluble sugars and crude protein and the possibility of bioactivity of the secondary plant compounds known to exist in some botanical essences. A moderate content of condensed tannins, for example, contributes to mitigate ruminal protein degradation, exercising a by-pass effect on dietary protein that in turn tends to reduce nonprotein N excretion (Makkar, 2003).

Botanical diversity of different pastures is also evident on fatty acid composition of cheese fat, according to pasture type strictly linked to soil characteristics (Povolo et al., 2012; Thomet et al., 2010).

\section{Effects of pasture on quality of animal products}

Pasture feeding has important effects on sensory properties and health benefits of dairy and meat products, since the herbage ingested by animals provides them with compounds with aromatic and functional properties. Most of these compounds exert an antioxidant effect that helps reduce the risk of cardiovascular diseases and tumours and to increase the shelflife of dairy products, preventing the oxidative degradation of unsaturated fatty acids and cholesterol. They can also be used as biological markers for traceability of animals' diet at pasture (Prache et al., 2005).

Milk produced by animals fed on pastures characterised by high botanical diversity and abundant aromatic essences is naturally rich in aromatic volatile compounds that are found in higher concentrations in cheese (Tornambè et al., 2006). The most studied are the terpenes, a large group of unsaturated hydrocarbons, divided into monoterpenes and sesquiterpenes, originating from the secondary metabolism of plants, especially dicotyledons (such as Apiaceae, Lamiaceae, Asteraceae, and, to a lesser extent, Poaceae), and characterised by an intense smell. Therefore, the content of terpenes in products from ruminants is a function of the botanical composition of pasture, especially of the plant species grazed by animals (Fedele et al., 2004), and it is considered to be responsible for the aromatic profile of milk and cheese, contributing to their sensory characteristics. Indeed, milk from goats grazing a natural pasture showed an approximately 4-fold higher content of sesquiterpenes than milk from goats fed hay (Fedele et al., 2005). The terpene content in cheese manufactured with cows' milk fed exclusively on pasture was markedly higher than that in cheese from cows housed indoors and fed a hay-based diet (Table 2), and this difference was seen at a sensorial level by a group of panelists (Bonanno et al., 2004). Accordingly, the presence of terpenes in dairy products (Tornambè et al., 2006) and meat (Vasta and Priolo, 2006) is considered a biomarker of pasture feeding, as well as of geographical origin and production period.
Carotenoid pigments, such as lutein and $\beta$-carotene, are present in high amounts in green forage, whereas their content is reduced by 70 $90 \%$ in conserved forage (Prache et al., 2005). In part, carotenoids are stored in the lipids of milk fat and adipose tissue and give them a yellow colour. In contrast to cattle, sheep and goats convert carotenoids into vitamin $\mathrm{A}$; therefore, the fat of their dairy products and meat remains white. The yellowness index (Hunter $b^{*}$ ), evaluating the intensity of the yellow colour of bovine milk and cheese, is an indicator of the presence of carotenoids and, considering the higher values observed on milk (Pagano and Avondo, 2009) and cheese (Carpino et al., 2004) from grazing cows compared to the products from cows housed indoor, may be a good biomarker of pasture feeding. Moreover, pasture feeding, compared to a hay-based diet, has been shown to enrich cheese also with some fat-soluble vitamins able to exert an antioxidant effect, such as trans-retinol and cis-retinol, or vitamin A, and $\alpha$-tocopherol or vitamin E (Bonanno et al., 2004) (Table 2).

Forages are rich in phenolic compounds, secondary metabolites of plants which can perform beneficial functions to animal and/or human organisms (El Gharras, 2009), and are interesting also for diet traceability purposes (Prache et al., 2005). Among them, flavonoids are the most represented. These are a group of polyphenolic pigments characterised by potent antioxidant properties (O'Connell and Fox, 2001; Poulet et al., 2002). The presence of polyphenols in ruminants' diets has the potential to: i) help optimise rumen fermentation and so mitigate methane emissions into the environment (Staerfl et al., 2010); ii) reduce the protein degradation in the rumen (such as condensed tannins) thus increasing aminoacid availability for intestinal absorption and reducing nitrogen excretions into the environment (Min et al., 2003 ); iii) protect the healthy polyunsatured fatty acids (PUFA) from rumen bio-hydrogenation, facilitating their transfer in dairy products and meat (Vasta et al., 2008); iv) improve oxidative protection and immune defenses, and, therefore, the health status of animals (Miller et al., 1993). Moreover, as some of the flavonoids are transferred from forage into milk (Besle et al., 2004), the intake of flavonoids by grazing animals can have interesting effects on the health properties of dairy products for consumers.

In dairy products and meat of ruminants, the content of long-chain PUFA, that are not synthesised by ruminant tissues and are derived exclusively from the diet, is particularly enhanced by pasture feeding, since the herbage is rich in PUFA, mainly consisting of $\alpha$-linolenic acid (ALA, C18:3n-3).

The importance of PUFA is linked to their beneficial effects on human health, especially in the prevention of coronary heart disease and in relation to their potential anticarcinogenic properties (Schmitz and Ecker, 2008). In particular, rumenic acid (cis-9, trans-11 C18:2, $\mathrm{RA})$, the principal isomer of conjugated linoleic acid found in ruminant products, derived from the ruminal biohydrogenation of ALA, shows antioxidant, anticarcinogenic and antiatherogenic properties, and is involved in the control of diabetes, osteogenesis, obesity and immune function (Banni et al., 2002). In general, when there is a greater intake from pasture in the diet, a proportional increase in ALA, RA and vaccenic acid (trans-11 C18:1, VA) has been observed in milk fat (Couvreur et al., 2006; Ferlay et al., 2008). These cow milk fatty acids increase noticeably when passing from cow-shed conditions to farm pastures and, to an even greater extent, to alpine pastures (Battaglini et al., 2003b, 2009). This is related to the high content of ALA in pastures, which is partly bio-hydrogenated into VA and partly absorbed in the intestinal tract and secreted into the milk. Moreover, in mammary gland, the VA is partly converted in RA by the action of the $\Delta-9$ desaturase enzyme (Antongiovanni, 2003; Bauman et al., 2006). For this reason, ALA, RA and VA can be used as a marker of the products obtained from grazing animals and, due to their recognised health properties, are also considered to be an indicator of the quality of the supply chain 
of livestock products. Similarly, the omega-6:omega-3 ratio, being lower in milk from grazing cows than milk from cows fed hay or a silagebased diet (Pagano and Avondo, 2009), has been shown to have the potential to discriminate animal diet.

Accordingly, the pasture-based diet of cows led to production of cheeses with a fatty acid profile that is more beneficial to human health than that of cheese from cows fed hay and concentrate, since it was richer in VA, RA, ALA, PUFA and omega-3, and had a reduced omega-6:omega-3 ratio (Bonanno et al., 2013) (Table 2). This pattern is also evident for some north Italian cheeses made from cows' milk, such as Asiago [appellation of origin (DOP)] (Renna et al., 2012) and Fontina (DOP), irrespective of the organic or conventional origin of the cheese (Renna et al., 2009).

\section{Conclusions}

Appropriate pasture management can contribute to soil conservation, differentiating between ecological conditions on different soils, thus creating several pasture vegetation types, a unique patrimony of great value in terms of biodiversity and capability to sustain local production activities. In fact, pasture biodiversity has a determining role in the qualification of animal products, confering typical characteristics related to aromatic compounds and health-promoting properties linked to the functional substances transferred from the plants ingested by grazing animals.

Operative models are needed to characterise and distinguish typical pastoral production systems. The approach must be systemic through the investigation of the main components, including soil, pasture resources, livestock, processing and product quality to assess the relationships between them, to allow traceability models, e.g. from soil through pasture to animal products, and to obtain technical information to improve the efficiency of pastoral production systems.

Funding and resources must be provided to foster the growth of these systems not only to support activities aimed at increasing production, but also to deal with different external factors and services in favour of the environment, including carbon footprint mitigation.

\section{References}

Argenti G, Lombardi G, 2012. The pasture-type approach for mountain pasture description and management. Ital. J. Agron. 2012;7:e39.

Banni S, Murru E, Angioni E, Carta G, Melis MP, 2002. Conjugated linoleic acid isomers (CLA): good for everything? Sci. Aliments 22:371-80.

Barger IA, Siale K, Banks DJD, Le Jambre LF, 1994. Rotational grazing for control of gastrointestinal nematodes of goats in a wet tropical environment. Vet Parasitol. 53:109-16.

Battaglini LM, Ighina A, Lussiana C, Mimosi A, Bianchi M, 2006. Livestock farming systems and milk production characteristics in some mountain areas of North-West Italy. In: R. Rubino, L. Sepe, A. Dimitriadou, A. Gibon (eds.) Livestock farming systems. Product quality based on local resources leading to improved sustainability. Vol. 118. Academic press, Wageningen, pp 199-203.

Battaglini LM, Biagini D, Brunetto E, 2003a. The livestock role in a piedmont alpine valley: multifuctionality and sustainability in "Val Germanasca" (N-W Italy). In: 5th IFSA European Symposium. Firenze. CESAI Accademia dei Georgofili, Firenze, pp 789-90.

Battaglini L, Lussiana C, Mimosi M, Ighina A, Linty C, 2003b. Milk yield and quality of Aosta Chestnut dairy cows grazing on alpine pas- tures. pp 123-130 in Atti 38th Simp. Int. Zootecnia, Lodi, Italy.

Battaglini LM, Renna M, Garda A, Lussiana C, Malfatto V, Mimosi A, Bianchi M, 2009. Comparing milk yield, chemical properties and somatic cell count from organic and conventional mountain farming systems. Ital. J. Anim. Sci. 8:384-6.

Bauman DE, Mather IH, Wall RJ, Lock AL, 2006. Major advances associated with the biosynthesis of milk. J Dairy Sci 89:1235-43.

Besle JM, Lamaison JL, Pradel P, Fraisse D, Viala D, Martin B, 2004. Les flavonoïdes, des fourrages au lait. pp 67-70 in Proc. 11th Renc. Rech. Rumin., Paris, France.

Bonanno A, Di Grigoli A, Alicata ML, Tornambè G, Avondo M, Pagano R, Giambalvo D, Stringi L, Di Miceli G, 2007a. Effect of stocking rate on selective behaviour and milk production of Girgentana goats grazing a ryegrass and berseem clover mixture. Options Mèditerranèennes série A: Séminanaires Méditerranéens 74:3517.

Bonanno A, Di Grigoli A, Stringi L, Di Miceli G, Giambalvo D, Tornambè G, Vargetto D, Alicata ML, 2007b. Intake and milk production of goats grazing sulla forage under different stocking rates. Ital. J. Anim. Sci. 6:605-7.

Bonanno A, Di Grigoli A, Tornambè G, Formoso B, Alicata ML, Procida G, Manzi P, Marconi S, Pizzoferrato L, 2004. Effects of feeding regime on nutritional and aromatic characteristics of Caciocavallo Palermitano cheese. pp 43-50 in Proc. $6^{\text {th }}$ Int. Meeting on Mountain Cheeses. Consorzio Ricerca Filiera Lattiero-Casearia (CoRFiLaC), Ragusa, Italy.

Bonanno A, Fedele V, Di Grigoli A, 2008. Grazing management of dairy goats on Mediterranean herbaceous pastures. In: A. Cannas and G. Pulina (eds.) Dairy goats feeding and nutrition. CAB International, Wallingford, UK, pp 189-220.

Bonanno A, Tornambè G, Bellina V, De Pasquale C, Mazza F, Maniaci G, Di Grigoli A, 2013. Effect of farming system and cheesemaking technology on the physicochemical characteristics, fatty acid profile, and sensory properties of Caciocavallo Palermitano cheese. J. Dairy Sci. 96:710-24.

Boval M. Dixon RM, 2012. The importance of grasslands for animal production and other functions: a review on management and methodological progress in the tropics. Animal 1:1-15.

Bugaud C, Buchin S, Coulon JB, Hauwuy A, 2001. Relationship between flavour and chemical composition of Abondance cheese derived from different types of pastures. Lait 81:757-73.

Carpino S, Horne J, Melilli C, Licitra G, Barbano DM, Van Soest PJ, 2004. Contribution of native pasture to the sensory properties of Ragusano cheese. J. Dairy Sci. 87:308-15.

Cavallero A, Ciotti A, 1991. Aspetti agronomici dell'utilizzazione dei prati e dei pascoli. Riv. Agron. 25:81-126.

Couvreur S, Hurtaud C, Lopez C, Delaby L, Peyraud JL, 2006. The linear relationship between the proportion of fresh grass in the diet of cows, milk fatty acid composition, and butter properties. J. Dairy Sci. 89:1956-69.

d'Angelo M, Enne G, Madrau S, Percich L, Previtali F, Pulina G, Zucca C, 2000. Mitigating land degradation in Mediterranean agro-silvopastoral systems: a GIS-based approach. Catena 2000;40:37-49.

d'Angelo M, Madrau S, Pulina G, Enne G, 1999. Land cover change as land degradation indicator in areas characterised by high antropic pressure due to agropastoral activities. Options Mediteraneennes 38:195-9.

Di Grigoli A, Pollicardo A, Mele M, Bonanno A, Tornambè G, Vargetto D, 2009. Effect of substitution of barley and tickbean to maize and extruded soybean in the diet on milk and cheese from ewes grazing under two different stocking rates. Options Mèditerranèennes, Séries A: Mediterranean Seminars 85:459-64.

Di Grigoli A, Todaro M, Di Miceli G, Genna V, Tornambè G, Alicata ML, 
Giambalvo D, Bonanno A, 2012. Effects of continuous and rotational grazing of different forage species on ewe milk production. Small Ruminant Res. 106S:S29-36.

El Gharras H, 2009. Polyphenols: food sources, properties and applications - a review. Int. J. Food Sci. Tech. 44:2512-8.

Enne G, Pulina G, d'Angelo M, Masala G, 1998. The role of animal grazing behaviour on land degradation in Mediterranean environments. Agric. Mediterranea 128:126-31.

Enne G, Pulina G, d'Angelo M, Previtali F, Madrau S, Caredda S, Francesconi AHD, 2002. Agropastoral activities and land degradation in Mediterranean areas: the case study of Sardinia. In: N.A. Geeson, C.J. Brandt, J.B. Thornes (eds.) mediterranean desertification: a mosaic of processes and responses. John Wiley \& Sons, Chichester, UK, pp 71-81.

Fedele V, Claps S, Rubino R, Sepe I, Cifuni GF, 2004. Variation in terpenes content and profile in milk in relation to the dominant plants in the diet of grazing goats. S. Afr. J. Anim. Sci. 34:202-4.

Fedele V, Claps S, Rubino R, Sepe I, Cifuni GF, 2005. Volatile compounds in herbage intake by goats in two different grazing seasons. Options Méditerranéennes. 67:261-7.

Ferlay A, Agabriel C, Sibra C, Journal C, Martin B, Chilliard Y, 2008. Tanker milk variability in fatty acids according to farm feeding and husbandry practices in a French semi-mountain area. Dairy Sci. Technol. 88:193-215.

Garnett T, 2010. Intensive versus extensive livestock systems and greenhouse gas emissions. FCRN briefing paper, January 2010. Food Climate Research Network, Oxford, UK, available from: http://www.fcrn.org.uk/

Gillet F, Kohler F, Vandenberghe C, Buttler A, 2010. Effect of dung deposition on small-scale patch structure and seasonal vegetation dynamics in mountain pastures. Agric. Ecosyst. Environ. 135:34-41.

Grappin R, Coulon JB, 1996. Terroir, lait et fromage: éléments de réflexion. Rencon. Recher. Rumin. 3:21-8.

Gusmeroli F, 2012. Prati, pascoli e paesaggio alpino. SoZooAlp, San Michele all'Adige (TN), Italy, available from: http://www.sozooalp.it/ fileadmin/superuser/altre_pubblicazioni/prati_pascoli_paesaggio_alpino_ld.pdf

Gusmeroli F, Battaglini LM, Bovolenta S, Corti M, Cozzi G, Dallagiacoma E, Mattiello S, Noè L, Paoletti R, Venerus S, Ventura W, 2010. La zootecnia alpina di fronte alle sfide del cambiamento. In: S. Bovolenta (ed) Benessere animale e sistemi zootecnici alpini. Quaderni SoZooAlp, San Michele all'Adige (TN), Italy, 6:9-22.

Heitschmidt RK, Stuth JW, 1991. Grazing management: an ecological perspective. Timber Press, Portland, OR, USA.

Inyang U, Vendramini JMB, Sollenberger LE, Sellers B, Adesogan A, Paiva L, Lunpha A, 2010. Forage species and stocking rate effects on animal performance and herbage responses of 'Mulato'and bahiagrass pastures. Crop Sci. 50:1079-85.

Iocola I, Latte G, Pittalis D, Lo Presti S, Pulina G, 2009. Impact of pastoralism on desertification processes. page 1 in Atti GEOITALIA, VI forum Italiano di Scienze della Terra, Rimini, Italy.

Kohler F, Gillet F, Gobat J-M, Buttler A, 2004. Seasonal vegetation changes in mountain pastures due to simulated effects of cattle grazing. J. Veg. Sci. 15:143-50.

Madrau S, Loj G, Baldaccini P, 1999. A model for evaluating the sustainability of grazing land to the Sardinian soil. In: The Medalus Project. Ed ERSAT, Cagliari, Italy, pp 1-52.

Makkar HPS, 2003. Effects and fate of tannins in ruminant animals, adaptation to tannins, and strategies to overcome detrimental effect of feeding tannin rich feeds. Small Ruminant Res. 49:241-56.

Metera E, Sakowski T, Słoniewski K, Romanowicz B, 2010. Grazing as a tool to mantain biodiversity of grassland - a review. Anim. Sci. Pap. Rep. 28:315-34.
Miller JK, Brzezinska-Slebodzinska E, Madsen FC, 1993. Oxidative stress, antioxidants, and animal function. J. Dairy. Sci. 76:2812-23.

Min BR, Barry TN, Attwood GT, McNabb WC, 2003. The effect of condensed tannins on the nutrition and health of ruminants feed fresh temperate forages: a review. Anim. Feed Sci. Technol. 106:3-19.

0'Connell JE, Fox PF, 2001. Significance and applications of phenolic compounds in the production and quality of milk and dairy products: a review. Int. Dairy J. 11:103-20.

Pagano RI, Avondo M 2009. Traceability of pasture feeding using some fatty acids and spectrophotometric parameters in milk. Ital. J. Anim. Sci. 8:426-8.

Papanastasis VP, 1999. Grasslands and woody plants in Europe with special reference to Greece. In: V.P. Papanastasis, J. Frame, A.S. Nastis (eds.) Proc. Int. Occasional Symposium of the European Grassland Federation: Grasslands and Woody Plants in Europe, Thessaloniki (Greece). Grasslands Sci. Eur. 4:15-24.

Poulet JL, Fraisse D, Viala D, Carnat A, Pradel P, Martin B, Lamaison JL, Belese JM, 2002. Flavonoids in forages: composition and possible effects on milk quality. pp 590-591 in Proc. 19th General Meeting of the European Grassland Federation, La Rochelle, France.

Povolo M, Pelizzola V, Lombardi G, Tava A, Contarini G, 2012. Hydrocarbon and fatty acid composition of cheese as affected by the pasture vegetation type. J. Agric. Food Chem. 60:299-308.

Prache S, Cornu A, Berdagu JL, Priolo A, 2005. Traceability of animal feeding diet in the meat and milk of small ruminants. Small Ruminant Res. 59:157-68.

Provenza FD, Villalba JJ, Dziba LE, Atwood SB, Banner RE, 2003. Linking herbivore experience, varied diets, and plant biochemical diversity. Small Ruminant Res. 49:257-74.

Pulina G, Masala G, Zanda A, Enne G, 1995. Analysis of biomass balance and stocking rate in cattle and sheep production system in mediterranean areas. Medit. 6:27-30.

Pulina G, Zucca C, 1999. Un nuovo indicatore territoriale per la valutazione dell'impatto del pascolamento. L'Inf. Agr. 55:105-9.

Pulina G, Zucca C, d'Angelo M, Nolis S, Enne G, 2002. Modelli di determinazione del carico di impatto animale in sistemi pascolativi e silvani. pp 47-71 in G. Enne and G.F. Greppi (eds) Atti 37th Simp. Int. Zootecnia "Zootecnia di montagna: valorizzazione dell'agricoltura biologica e del territorio", Madonna di Campiglio, Trento, Italy.

Ramanzin M, Battaglini LM, Morbidini L, Pauselli M, Pulina G, 2009. Evoluzione dei sistemi zootecnici e trasformazione del paesaggio. Ital. J. Agron. 4:19-23.

Renna M, Cornale P, Lussiana C, Giordano M, Belviso S, Zeppa G, Battaglini LM, 2012. Efficacy of fatty acids and terpenoids and weakness of electronic nose response as tracers of Asiago d'Allevo PD0 cheese produced in different seasons. Dairy Sci. Technol. 92:203-18.

Renna M, Garda A, Lussiana C, Ambrosoli R, Battaglini LM, 2009. Chemical, nutritional and microbiological characterization of organic Fontina PD0 cheese. Ital. J. Food. Sci. 21:287-303.

Rogiers N, Conen F, Furger M, Stöckli R, Eugster W, 2008. Impact of past and present land-management on the $\mathrm{C}$-balance of a grassland in the Swiss Alps. Glob Change Biol. 14:2613-25.

Rook AJ, Dumont B, Isselstein J, Osoro K, WallisDeVries MF, Parente G, Mills J. 2004. Matching type of livestock to desired biodiversity outcomes in pastures - a review. Biol. Conserv. 119:137-50.

Rosenthal G, Schrautzer J, Eichberg C, 2012. Low-intensity grazing with domestic herbivores: A tool for maintaining and restoring plant diversity in temperate Europe. Tuexenia 32:167-205.

Schmitz G, Ecker J, 2008. The opposing effects of n-3 and n-6 fatty acids. Progr. Lipid Res. 47:147-55.

Sepe L, Claps S, Fedele V, 2011. Effectiveness of specific stocking rates to avoid habitat deterioration, applied in accordance to the Italian 
GAEC standard 4.6 (ex 4.1c) of cross compliance. Ital. J. Agron. 6(s1):e17.

Soder KJ, Rook AJ, Sanderson MA, Goslee SC, 2007. Interaction of plant species diversity on grazing behavior and performance of livestock grazing temperate region pastures. Crop Sci. 47:416-25.

Soussana JF, Tallec T, Blanfort V, 2010. Mitigating the greenhouse gas balance of ruminant production systems through carbon sequestration in grasslands. Animal 4:334-50.

Staerfl SM, Kreuzer M, Soliva CR, 2010. In vitro screening of unconventional feeds and various natural supplements for their ruminal methane mitigation potential when included in a maize-silage based diet. J. Anim. Feed. Sci. 19:651-64.

Thomet P, Cutullic E, Bisig W, Wuest C, Elsaesser M, Steinberger S, Steinwidder A, 2010. Merits of full grazing systems as a sustainable and efficient milk production strategy. Grassland farming and land management systems in mountainous regions. In: E.M. Pötsch, B. Krautzer, A. Hopkins (eds.) Proc. 16th Symp. Eur. Grassland Federation, Gumpenstein, Austria, 16:273-85.

Tornambè G, Cornu A, Pradel P, Kondjoyan N, Carnat AP, Petit M, Martin $\mathrm{B}, 2006$. Changes in terpene content in milk from pasture-fed cows. J. Dairy Sci. 89:2309-19.

Totty VK, Greenwood SL, Bryant RH, Edwards GR, 2013. Nitrogen partitioning and milk production of dairy cows grazing simple and diverse pastures. J. Dairy Sci. 96:141-9.

Vasta V, Priolo A, 2006. Ruminant fat volatiles as affected by diet. A review. Meat. Sci. 73:218-28.

Vasta V, Nudda A, Cannas A, Lanza M, Priolo A, 2008. Alternative feed resources and their effects on the quality of meat and milk from small ruminants. Anim. Feed Sci. Technol. 147:223-46. 